\title{
CIÊNCIA, SOCIEDADE E (POR QUE NÃO?) NATUREZA: A PROPÓSITO DE UMA AGENDA PARA SCIENCE STUDIES
}

Science, Society and (why not?) Nature: apropos of an agenda for science studies

Eduardo Salles de Oliveira Barra

\section{Resumo}

Nos últimos vinte anos, os science studies (estudos sobre a ciência) se consolidaram como uma disciplina programaticamente comprometida com a revisão da imagem da ciência que cientistas ativos, filósofos e historiadores da ciência haviam propagado ao longo do século 20. Neste artigo, pretendo fazer uma apresentação e uma discussão das teses centrais de dois dos seus mais importantes representantes, Bruno Latour e David Bloor. Tomo como ponto de partida o debate que ficou conhecido como a "guerra das ciências", desencadeado pela reação aos questionamentos lançados pelos science studies às teses tradicionais do racionalismo e do realismo científicos. Não me posiciono a favor de nenhuma das duas posições extremas em disputa, mas manifesto minha inclinação por posições que ofereçam um "meio termo" entre ambas. Meu objetivo é apenas avaliar o quanto algumas respostas mais recentes àquelas reações avançaram no cumprimento da agenda proposta por Philip Kitcher (1998) para o futuro dos science studies.

Palavras-chave: Construtivismo social. Relativismo epistemológico. Realismo científico. Guerra das ciências. Programa Forte em Sociologia do Conhecimento. 


\begin{abstract}
In the last twenty years, the science studies were consolidate as a discipline programmatically committed to a revision of the image of science which active scientists, philosophers and historians of science had diffused at the 20th century. In this paper, I aim to reconstruct and to discuss the main thesis of two of its more important players: Bruno Latour and David Bloor. I take as a starting-point the dispute which was made known as the "war of sciences", initiated by the reaction against the science studies criticism to the traditional thesis of the scientific rationalism and realism. I do not place myself in favor of any of the extreme positions at strife. My claim is only to evaluate how much some of the most recent replies to these reactions progressed in accomplishing the agenda proposed by Philip Kitcher (1998) for the future of the science studies.
\end{abstract}

Keywords: Social constructivism. Epistemological relativism. Scientific realism. Sciences War. Strong Program in Sociology of Knowledge.

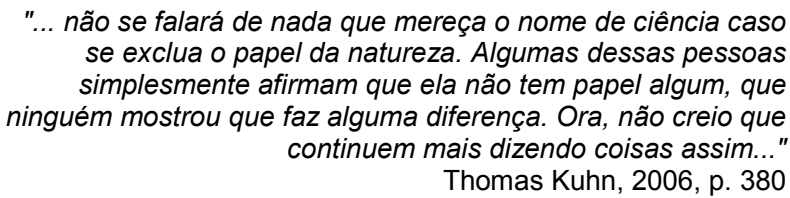
se exclua o papel da natureza. Algumas dessas pessoas simplesmente afirmam que ela não tem papel algum, que ninguém mostrou que faz alguma diferença. Ora, não creio que continuem mais dizendo coisas assim..." Thomas Kuhn, 2006, p. 380

\title{
No começo, uma fábula de Latour
}

Inicio minha discussão apresentando uma paráfrase de uma fábula contada por Bruno Latour. A fim de ilustrar a mistificação que fazem o cientista e o tecnólogo da natureza de seu próprio trabalho, Latour lança mão de um relato imaginário do tormento vivido por um certo sociólogo da ciência em decorrência de um sonho. O sociólogo imaginário de Latour sonhou que pretendia estabelecer a ordem genealógica correta para o aparecimento de três inusitados personagens, a saber, o popsauro, o cientosauro e o realsauro. Em oposição às pretensões do sociólogo estavam os 
paleontólogos, que consideravam a sua questão absurda, pois o mais antigo era obviamente o realsauro, que tinha milhões de anos, enquanto o cientosauro só havia começado a se desenvolver nos últimos 150 anos. De nada adiantava o sociólogo argumentar que, cada vez que o cientosauro se transformava, com novos dados e teorias, o realsauro também se modificava, tornando óbvia a precedência do primeiro sobre o segundo. Ao final, frustrado e desmoralizado pelos paleontólogos, o sociólogo resolveu estudar o popsauro, tal como ele aparecia no cinema, nas histórias em quadrinhos e nos programas de televisão, e concluiu que, em grande parte, era de fato o popsauro que determinava as características do realsauro. Contudo, antes de escrever seu trabalho, cuja publicação significaria sem dúvida o fim de sua reputação científica, o sociólogo acordou (LATOUR, 1993; SHARTZMAN, 1994, p. 176-177).

A primeira coisa a ser observada sobre essa narrativa é que a conotação de fábula que Latour lhe confere não deve ser mais uma fonte de ilusões: muitos sociólogos, historiadores e filósofos da ciência pensam exatamente como o sociólogo da fábula quando estão bem despertos e a atitude de aferrarem-se a seus "sonhos antidogmáticos", ao contrário do que sugere a moral negativa da narrativa de Latour, tem Ihes propiciado prestígio acadêmico e sucesso editorial. Mas isso é ainda um aspecto periférico das questões em torno da fábula acima. O mais importante surge quando podemos especificar melhor a base da polêmica entre o sociólogo e o paleontólogo. A polêmica parece não versar apenas sobre uma questão de precedência genética, acerca de "quem nasceu primeiro" ou de "quem gerou quem", mas acima de tudo sobre uma questão de precedência lógica, expressa na conclusão de que o popsauro "determinava as características do realsauro". O principal argumento aludido para sustentar essa conclusão parte de uma pressuposição comum a muitas versões do relativismo epistemológico: é uma ilusão pensar que o mundo real exerça qualquer função na formação e na aceitação das crenças científicas, pois aquilo que consideramos ser o "mundo" e nossas "evidências" acerca dele não existem independentemente de nossas crenças científicas e nãocientíficas a seu respeito. 
A pressuposição relativista está firmemente apoiada na convicção de que as mudanças que verificamos no realsauro - isto é, naquilo que consideramos ser o "mundo" ou nossas evidências acerca dele - são precedidas e determinadas por transformações anteriores no cientosauro, e não o contrário, conforme suponha o paleontólogo de Latour. Mas a fábula nos fornece elementos para levarmos um pouco mais adiante essa cadeia de determinações. A próxima pergunta seria, então, se é o cientosauro que determina o realsauro, o que determina, por sua vez, o cientosauro? De acordo com a moral do sonho antidogmático do sociólogo de Latour, as crenças científicas não se estruturam independentemente das visões de mundo que permeiam as sociedades. Mais que isso, aquelas primeiras são genuinamente determinadas por essas últimas. Portanto, se há algo com o que a gênese e a justificação de nossas crenças científicas devem estar estreitamente relacionadas, isso não seria o "mundo" (isto é, o habitat do realsauro), mas as ideologias socialmente compartilhadas - sejam elas de ordem política, religiosa, moral ou estética (isto é, o habitat do popsauro). Em uma palavra, a ciência e o mundo que ele pretende descrever e explicar são, irresistivelmente, construções sociais.

Desnecessário dizer que a moral da fábula de Latour contraria diretamente a imagem tradicional que os cientistas (e, com eles, muitos filósofos e historiadores da ciência) fazem a respeito de seu próprio trabalho. O Prêmio Nobel de física, Steven Weinberg, foi um dos mais contundentes críticos aos divulgadores desse tipo de imagem das teorias científicas como construtos "moldadas exclusivamente por forças históricas e sociais". Num capítulo intitulado sem rodeios "Contra os filósofos", Weinberg sustenta que

os cientistas mudam de opinião várias vezes, em resposta a cálculos e experiências até que, finalmente, uma visão ou outra tenha uma marca inconfundível de sucesso objetivo. Estou certo de que estamos descobrindo algo de real na física, cuja forma de ser não tem qualquer conexão com as condições sociais ou históricas que nos permitam descobri-lo [...] (WEINBERG, 1996, p. 45. Grifos do autor). 
Os pontos de vista de Weinberg têm ao menos, dois pontos em comum com a talvez mais popular imagem da ciência surgida durante o século 20 , vagamente identificada como positivismo ou empirismo lógico, quais sejam, a convicção de que a ciência opera irrevogavelmente segundo um método estruturado na comparação entre as teorias propostas e um conjunto estável de evidências disponíveis - esse método cuja aplicação rigorosa assegura que as mudanças na ciência, isto é, a substituição de uma antiga teoria por uma outra recém proposta, ocorram exclusivamente "em resposta a cálculos e experiências" - e que as teorias científicas consolidadas representam predominantemente fatos objetivos - fatos esses que, reunidos, constituem o "real" ou aquilo que se pode dizer que "estamos descobrindo".

Os alvos das críticas de Weinberg não são, contudo, exclusivamente os filósofos. Elas se dirigem a um espectro bem mais diversificado de praticantes das ciências humanas - uma boa parte deles inteiramente afinada com o modo de pensar do sociólogo da fábula de Latour agrupados nos assim chamados science studies (literalmente, estudos sobre a ciência), um campo de investigação sobre as práticas científicas constituído nas últimas duas décadas a partir de instrumentais analíticos oriundos das disciplinas tradicionais das ciências humanas, tais como a filosofia, a história, a sociologia e os estudos literários. O tipo de reação exemplificada pelas críticas de Weiberg ao construtivismo social promovido pelos science studies passou então a ser conhecido como a "guerra das ciências" (sciences war), episódio que ganhou destaque na primeira página de uma edição diária do The New York Times em virtude do embuste que Alan Sokal aplicou à revista Social Text (SOKAL e BRICMONT, 1999). Não foi desprezível, portanto, a reação à disseminação da imagem da empresa científica sob o domínio hegemônico do popsauro defendida pelo sociólogo imaginário da fábula de Latour e seus aliados reais (ou, ao menos, digamos, de carne e osso) no campo dos science studies. Após mais de vinte anos de discussões e polêmicas sobre os méritos intelectuais desse tipo de construtivismo social, é oportuno identificar suas conquistas e suas inevitáveis vítimas. 
Meu objetivo neste artigo é justamente fazer uma tal identificação, ainda que de modo parcial e provisório. Não pretendo, portanto, apresentar aqui um levantamento e uma discussão exaustiva de tudo que se sucedeu desde os primeiros movimentos da chamada guerra das ciências. Tomarei um ponto de partida bem particular para estabelecer uma provável agenda para a pacificação dos science studies e, à luz das tarefas ali propostas, procurarei identificar em alguns textos mais recentes os avanços para a sua consecução. De modo específico, partirei daquilo que Philip Kitcher considerou "pontos que deveriam ser incontestáveis" para a relevância e a continuidade dos science studies e, com base em artigos subsequentes de alguns dos seus mais representativos promotores (entre eles o próprio Latour), procurarei identificar o quanto cumpriram em suas respectivas análises da ciência a agenda proposta por ele.

\section{A agenda de Kitcher para os science studies}

Tracei acima um cenário que sugere uma acirrada polarização entre duas imagens da ciência: de um lado, a ciência popsáurica trazida à luz pelo construtivismo social dos recentes science studies e, de outro lado, a ciência realsáurica urdida à sombra do espectro de um positivismo extemporâneo. Seria ainda possível vislumbrar uma terceira posição, intermediária entre ambas as contendoras? A resposta que virtualmente seria dada por Philip Kitcher a esse tipo de pergunta seria um sonoro "sim". Obviamente, ele não pensa ser necessário oferecer algum conjunto de teses que, tomadas individualmente, não houvessem sido propostas ou defendidas por qualquer um dos dois lados em disputa. Ao contrário, ele tenciona erigir uma imagem geral e coerente das práticas científicas capaz de acomodar pontos que representam versões parciais ou mesmo integrais de teses tradicionalmente sustentadas por lados opostos da disputa. Isso ele o faz num artigo concebido como uma defesa dos science studies contra o ataque de Sokal e Weinberg, por exemplo, mas como uma defesa condicionada à sua anuência a uma agenda comum, uma espécie de 
prolegômenos ao período pós-guerra das ciências. De maneira esquemática, a proposta de Kitcher consiste em, inicialmente, distinguir dois grupos de pontos que não poderiam estar ausentes, como pressupostos, em qualquer análise aceitável das práticas cientificas. Em primeiro lugar, os pontos racional-realistas $(R R)$ :

(RR1) Na maioria das áreas das ciências maduras, a pesquisa é progressiva e o seu caráter progressivo manifesta-se no crescente poder de predição e intervenção.

(RR2) O crescente poder de predição e intervenção justifica afirmar que os tipos de entidades descritas na pesquisa científica existem independentemente da nossa teorização acerca delas e que muitas das nossas descrições são aproximadamente verdadeiras.

(RR3) Nossas afirmações são, entretanto, vulneráveis a futuras refutações. Podemos legitimamente afirmar que nossas representações da natureza são aproximadamente verdadeiras, mesmo reconhecendo que poderemos ser obrigados a revisá-las no futuro.

(RR4) Nas áreas mais destacadas da ciência, nossas concepções estão sustentadas em evidências e as disputas são resolvidas mediante o recurso aos cânones da razão e da evidência.

(RR5) Os cânones da razão e da evidência também progridem com o passar do tempo, de tal modo que ampliamos o nosso conhecimento não somente acerca do mundo, mas também acerca dos meios pelos quais aprendemos algo sobre ele (KITCHER, 1998, p. 34-35).

Kitcher sustenta ser igualmente indispensável contemplar, em conjunto com o grupo de pontos acima, outro grupo de pontos histórico-sociais (HS):

(HS1) A ciência é realizada por seres humanos, isto é, por seres cognitivamente limitados que vivem em grupos sociais que, por sua vez, são dotados de uma complexa estrutura e de uma longa história.

(HS2) Nenhum cientista jamais abandona, ao adentrar o seu laboratório ou campo de estudo, as categorias e pré-concepções historicamente compartilhadas pelo grupo a que pertence. 
(HS3) As estruturas sociais interiorizadas na ciência influenciam o modo como a pesquisa é transmitida e recebida, a ponto de possivelmente repercutirem nos seus debates internos.

(HS4) As estruturas sociais nas quais a ciência está inserida influenciam a definição do tipo de questões significativas e, por vezes, do tipo de respostas que são propostas e aceitas (KITCHER, 1998, p. 36).

É desnecessário dizer que os autores dos science studies sempre estiveram preferencialmente interessados em salientar pontos do grupo HS em suas análises, enquanto os seus críticos, por contraporem-se à imagem da ciência "moldada exclusivamente por forças históricas e sociais", apoiam-se nos pontos do grupo RR. Por sua vez, Kitcher advoga em favor de uma visão que ele mesmo identificou como sendo um "meio termo", por pretender conciliar a totalidade dos pontos "incontestáveis" tanto do grupo RR quanto do grupo HS. Todavia, mesmo sendo um dos mais originais teóricos dos science studies das últimas décadas e se posicionar nesse artigo em defesa do seu próprio campo de investigação, Kitcher elege como o alvo prioritário das suas análises os equívocos cometidos por seus próprios pares ao ignorarem reiteradamente os pontos RR. Kitcher resume esses equívocos no que ele chamou de quatro dogmas dos science studies, nominalmente: (1) Não há nenhuma verdade; há somente aceitação social; (2) nenhum sistema de crenças é controlado pela razão ou pela realidade; não há nenhum sistema de crenças privilegiado; (3) não deve haver assimetria na explicação da verdade e da falsidade, ou da sociedade e da natureza; e (4) deve-se sempre privilegiar as "categorias dos agentes" (KITCHER, 1998, p. 44).

\section{Relativismo, "categorias dos agentes" e simetria}

Deve-se notar que cada um dos "dogmas" acima é uma forma direta ou indireta de contestar os pontos do grupo RR. A manutenção do dogma 2, por exemplo, impede a sustentação do ponto RR4, que confere um papel predominante à razão e à evidência no estabelecimento das crenças 
científicas. Abrir mão de RR4 significa, entre outras coisas, aderir ao relativismo epistemológico, isto é, admitir que todos os sistemas de crenças (científicas, religiosas, políticas, morais etc.) se equivalem do ponto de vista da sua justificação ou fundamentação, visto que nenhum deles pode reivindicar para si um vínculo mais estreito com os cânones da razão ou com a realidade. De modo menos óbvio, mas não menos eficaz, os dogmas 1 e 4 indiciam toda tentativa de sustentar o tipo de realismo científico autorizado pelo ponto RR2. Se os tipos de objetos (por exemplo, átomos, DNA, radiações, platôs tectônicos etc.) que povoam as teorias científicas não existem independentemente delas, sua admissão como objetos reais decorre exclusivamente de sua ampla aceitação social. Se for assim, o mesmo deve ocorrer com os tipos de objetos que no passado povoaram o discurso científico, tal como o flogístico a cuja ação os químicos do início do século XVIII atribuíam os fenômenos da combustão, ou a força vital à qual até o início do último século os biólogos recorriam para explicar, por exemplo, a regeneração de certos tecidos vivos, ou, por fim, os movimentos em epiciclos invocados pelos astrônomos ptolomaicos para representar as órbitas planetárias. Assim, o significado de termos tais como "flogístico", "força vital" ou "movimento epicicloidal", quando eles ocorrem nas narrativas dos historiadores contemporâneos, deve ser exclusivamente apreendido segundo as "categorias dos agentes", isto é, segundo o significado que originalmente foram atribuídos por aqueles que os conceberam e os acolheram em suas explicações. É óbvio que uma narrativa nesses termos pode ter propósitos explicativos importantes. Todavia, isso não deve significar que, por exemplo, a incidência e disseminação da peste bubônica durante a Idade Média na Europa não possa ser também compreendida com méritos a partir dos recursos teóricos da epidemiologia contemporânea, que poderiam nos explicar as razões da ineficácia das várias estratégias empregadas na época para combater a peste, do declínio natural da sua incidência e da imunidade endógena de certos indivíduos, entre outros aspectos. ${ }^{1}$

Por fim, tanto o relativismo epistemológico quanto o antirrealismo científico sustentam, ainda que indiretamente, a tese da simetria entre as 
explicações da verdade e da falsidade das crenças científicas incorporada ao dogma 3. Essa tese foi formulada por David Bloor no intuito de assegurar que ambas as qualidades opostas de nossas crenças (verdade e falsidade) fossem compreendidas mediante o apelo aos mesmos fatores causais. Tomemos o caso de dois cientistas que, em contextos sociais distintos, se dedicam à investigação dos mesmos fenômenos e disputam a adesão do restante da comunidade científica às suas respectivas conclusões divergentes. O eventual sucesso de um e o correspondente infortúnio do outro não deveriam ser atribuídos ao fato de as teses sustentadas pelo primeiro corresponder ao mundo material (e, assim, ser verdadeira), enquanto que o contrário ocorre com as teses do seu adversário. Para Bloor, essa é uma razão necessária, mas não suficiente:

\footnotetext{
A questão metodológica crucial no presente contexto é decidir o que exemplos desse tipo dizem sobre o papel da nossa experiência do mundo material nas explicações sociológicas da ciência. Argumentarei que levar em consideração a maneira como o mundo material se comporta não tem nenhuma conseqüência para a simetria ou para o caráter causal das explicações sociológicas. (BLOOR, 1991, p. 35-36)
}

Embora não seja suficientemente óbvio tudo o que Bloor pretende com essas considerações, está claro que ele quer afirmar ao menos que "a maneira como o mundo material se comporta" é indiferente para as explicações (sociológicas) das práticas da ciência. Outro conjunto de "crenças, padrões, valores e expectativas" socialmente compartilhados terá que ser invocado para explicar as diferenças no destino de dois programas de pesquisa rivais. Está igualmente claro que os respectivos conjuntos associados a cada um dos programas serão virtualmente distintos e que, portanto, terão efeitos particulares distintos. Todavia, por mais assimétricos que sejam os diferentes conjuntos de crenças, padrões, valores e expectativas socialmente compartilhadas associados a cada programa rival, nada disso irá comprometer a simetria entre o verdadeiro e o falso pretendida por Bloor. A assimetria que ele pretende combater não reside nos efeitos particulares de cada uma das causas, mas "reside no tipo de 
causas" (BLOOR, 1991, p. 36) incumbida de determinar o destino das crenças científicas. $^{2}$

Coube a Latour estender o argumento original de Bloor para além do par verdadeiro-falso e dar os contornos finais ao dogma 3. No seu influente livro Vida de Laboratório, em parceria com Woolgar, Latour sustenta que

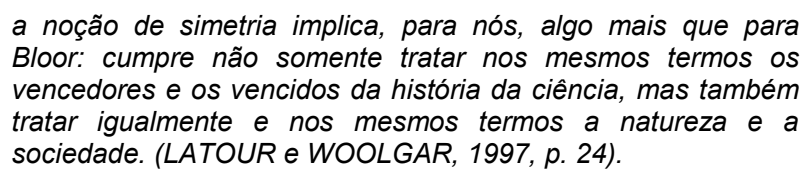

a noção de simetria implica, para nós, algo mais que para Bloor: cumpre não somente tratar nos mesmos termos os vencedores e os vencidos da história da ciência, mas também tratar igualmente e nos mesmos termos a natureza e a sociedade. (LATOUR e WOOLGAR, 1997, p. 24).

E adiante eles próprios retiram a consequência devastadora dessa nova simetria entre sociedade e natureza para as pretensões daqueles que reivindicam a necessidade de uma realidade independente e extra-teórica, nos termos do ponto RR2 acima: "A atividade científica não trata da 'natureza', ela é uma luta renhida para construir a realidade. [...] A realidade é, então, secretada." (LATOUR e WOOLGAR, 1997, p. 278) Portanto, combinando ambas as modalidades de simetria (verdadeiro-falso e sociedade-natureza), surge um quadro de dependência (tanto genética quanto lógica) que concorda inteiramente com a moral da fábula jurássica de Latour. Afinal, se não houver dúvida sobre a primazia do popsauro sobre todas as demais espécies do seu gênero, a simetria generalizada de Latour impõe as crenças, os padrões, os valores e as expectativas socialmente compartilhadas como as causas mais remotas da realidade construída pela ciência.

\section{Em busca da natureza perdida}

Tudo indica, todavia, que Latour não compartilha das opiniões do personagem principal da sua fábula. Ele não mais autorizaria a combinação acima sugerida entre os dois pares simétricos (verdade-falsidade e sociedade-natureza), de tal modo que, ao fim e ao cabo, nada além do popsauro teria eficácia causal e a realidade se resumiria numa construção da ciência (simetria entre sociedade e natureza), que, por sua vez, se 
resumiria numa construção da sociedade (simetria entre verdade e falsidade). Nos últimos anos, Latour passou a sustentar que nem mesmo se deve tentar explicar a natureza em termos da sociedade ou a sociedade em termos da natureza. O desafio seria, ao invés disso, explicar ambos em termos de um terceiro processo. Sociedade e natureza seriam "coproduzidos" - ou, nos termos da antiga fábula, popsauro e realsauro seriam congênitos. Amplia-se assim a simetria entre sociedade e natureza mediante a inclusão do compartilhamento igualitário da agência pelos sujeitos e objetos. Tudo isso colabora decisivamente para o intento manifesto de Latour, que quer nos convencer da necessidade de "mais uma nova virada após a virada [do construtivismo] social" (1992, p. 272). ${ }^{3}$

Contrariando a venerável tradição representada aqui por Weinberg e Sokal, Latour considera que nada pode ser mais fingida, forçada e acanhada do que "a noção de um mundo 'lá fora', ao qual uma mente extirpada tenta obter acesso estabelecendo alguma correspondência segura entre as palavras e estado de coisas [...]" (2001, p. 133) Todavia, a tentativa dos science studies de substituir essa noção por aquelas de "construção" e "fabricação" em suas explicações da transformação que os cientistas impõem ao mundo envolve dificuldades similares. Esse tipo de explicação restringe a iniciativa da ação à esfera humana (o mundo oferece apenas uma espécie de playground para o engenho humano), realizando assim um jogo de soma zero (entrada = saída) como se fosse uma mera combinação de ingredientes contidos numa lista fixa. O exemplo preferido de Latour para ilustrar suas teses anti-construtivistas é a história da explicação dos mecanismos da fermentação bacteriana e da consequente produção do ácido lático proposta por Louis Pasteur, na metade do século XIX. Para Latour, nesse episódio, é indispensável reconhecer que ambos, tanto Pasteur quanto o seu fermento, devem ser considerados agentes e serão, assim, coproduzidos.

Se ignoramos o trabalho de Pasteur, cairemos no poço do realismo ingênuo do qual 25 anos de estudos científicos [science studies] se esforçaram para nos tirar. Mas que acontecerá se ignorarmos a atividade autônoma, automática e delegada do ácido láctico? Cairemos em outro poço, tão fundo 
Para atribuir um papel aos "não-humanos" é preciso reconhecer simultaneamente que (1) o fermento do ácido lático é totalmente independente da construção humana; (2) o fermento do ácido lático não possui existência independente fora do trabalho executado por Pasteur; (3) o trabalho de Pasteur não deve ser considerado negativamente como mais uma entre outras tantas dúvidas sobre existência do fermento, mas positivamente como aquilo que lhe permite existir; (4) o experimento é um evento e não a mera recombinação de uma lista fixa de ingredientes prévios. Essa série de especificações é incompatível tanto com o construtivismo social quanto com o "realismo ingênuo" (muito provavelmente Latour tem em mente algo como o ponto RR2 acima); ambos fundados na divisão entre um mundo humano falante e um mundo nãohumano mudo, isto é, entre palavras e coisas, entre sujeito e objeto.

Mas deixemos temporariamente de lado a "simetria generalizada" de Latour para compreender melhor as bases do construtivismo social que ele atualmente tanto critica.

Se não o próprio Latour, então quem mais poderia encarnar o ideário de seu antigo personagem desperto logo após "descobrir" a precedência do popsauro sobre seus congêneres realsauro e cientosauro? Ou seja, quem são, afinal, os construtivistas sociais agora desafiados por Latour? A resposta é a mais direta possível: os principais representantes do Programa Forte em Sociologia do Conhecimento (referido daqui em diante apenas por "Programa Forte"), Barry Barnes e David Bloor. Coube a Bloor responder aos ataques de Latour, num artigo intitulado sem meiaspalavras "Anti-Latour" (1999). Pouco ou nada há nessa defesa do construtivismo social do Programa Forte que diga explicitamente respeito à agenda proposta por Kicther para os science studies. O interesse das idéias de Bloor para os propósitos deste artigo é que, a pretexto de restabelecer a distinção entre sujeito e objeto proscrita por Latour, elas promovem certa modalidade de realismo, da mesma forma como fizera o próprio Latour, por vias totalmente opostas, e, ainda que de modo indireto, restabelecem assim 
um ponto de contato com a agenda kitcheriana. Desse ponto de vista, o que interessa é a tentativa de Bloor de articular as posições do Programa Forte em relação ao realismo e ao relativismo:

Primeiro, o relativismo do Programa Forte não deve ser contraposto ao realismo. Conforme tenho enfatizado, a natureza (não-social) desempenha um papel central na formação da crença, embora o modo como a natureza submete-se à experiência não possa fornecer uma explicação causal suficiente do modo pelo qual será subseqüentemente descrita. [...] Essa posição é "relativista" porque não admite provas absolutas de que uma teoria científica é superior a uma outra: há apenas razões localmente críveis. [...] A idéia de Latour de que a simetria defendida pelo Programa Forte acarreta a igual credibilidade de todas as crenças está errada. O correto é que todas as teorias e crenças enfrentam igualmente problemas de credibilidade e que, portanto, diferentes espécies e graus de credibilidade demandam igualmente explicações causais. (BLOOR, 1999, p. 102. Grifos do autor.)

O argumento de Bloor, nessa passagem, é bastante complexo e precisa ser analisado detalhadamente. Primeiro, ele propõe uma clivagem no interior do grupo RR de Kitcher, de tal modo que seus aspectos realistas pudessem ser distinguidos dos seus aspectos, digamos, "racionalistas". Em cada um desses extremos, estariam respectivamente os pontos RR2 e RR4. O que Bloor parece pretender é que se possa aderir ao primeiro sem assentir ao segundo. Em suas próprias palavras, "a natureza (não-social) desempenha um papel central na formação da crença"; todavia, a credibilidade das crenças e teorias é uma função de fatores locais, isto é, não-universais ou não acessíveis mediante "provas absolutas". Daí o relativismo epistemológico e a simetria defendidos pelo Programa Forte: mesmo o grau mais superlativo de credibilidade (isto é, de aceitação) obtido por uma teoria científica não dispensa "explicações causais", isto é, explicações mediante "crenças, padrões, valores e expectativas" socialmente compartilhados. Visto que juízos distintos sobre tal credibilidade refletem diferenças indiscrimináveis nesses elementos socialmente compartilhados, é incorreto, todavia, pretender que tal relativismo acarrete "a igual credibilidade de todas as crenças". O relativismo articulado ao 
Programa Forte de Bloor jamais supõe a isonomia das crenças, uma vez que as sociedades que as promovem são (indefinidamente) diversas.

O relativismo, nesse ponto, corresponde à tese - típica do Programa Forte - de que todo conhecimento tem o caráter de uma instituição social. O desafio de Bloor será, então, conciliar essa tese com a sua contraparte realista, que exige de todo conhecimento legítimo também uma referência externa ou a correspondência a uma realidade independente. Obviamente, ele deve asseverar uma separação entre o mundo e a descrição que fazemos dele. Mas não se pode, com isso, supor que a aceitação ideal de uma determinada descrição seja função de sua relação de correspondência com o mundo. A correspondência em questão é "uma relação que os próprios atores afirmam ou imputam ou aceitam, mas não algo que opera como uma causa real." (BLOOR, 1999, p. 89) A correspondência deve, dessa forma, ser compreendida em sintonia com a autorreferência - algo que Bloor estende a toda atividade científica de conceituação, categorização e classificação:

\begin{abstract}
O desafio é combinar os dois processos, um constituído pela auto-referência e o outro envolvendo a referência externa. [...] Mesas e cadeiras, tigelas e sopas, assim como fertilizantes, explosivos, vacinas e corantes são todos coisas reais $e$ externas, mas coisas cuja identidade é definida pelo seu papel na vida de um grupo que cria essa identidade por meio de suas práticas. [...] [E]sses casos podem ser empregados como modelos para objetos cuja função em nossas vidas é mais sutil, tais como os elétrons e os micróbios [...]. A ligação entre a auto-referência e a referência externa é tal que a última pressupõe a primeira. A referência de um conjunto de conceitos a uma realidade externa torna-se possivel somente porque esse conjunto é coletivamente sustentado. Para que conteúdos conceituais sejam sustentados, deve haver princípios normativos que governem a aplicação dos conceitos. (BLOOR, 1999, p. 109. Grifos do autor.)
\end{abstract}

Imputar um certo construtivismo social ao Programa Forte, como faz Latour, não é, portanto, sem propósito; o construtivismo social aqui repousa sobre a tese de que as entidades teóricas da ciência (cujos exemplos de Bloor acima são elétrons e micróbios) são instituições sociais autorreferenciadas. Avaliar as crenças científicas como corretas ou incorretas é uma questão de decidir se os conceitos que empregam estão 
correta ou incorretamente aplicados, segundo critérios públicos de uso da linguagem. ${ }^{4}$ Isso implica que, para Bloor, analisar os conceitos como instituições sociais é condição para uma explicação da referência das crenças científicas (tidas como corretas ou verdadeiras) à realidade externa. É nesse sentido, portanto, que a referência à realidade externa, embora necessária, é insuficiente para assegurar a correspondência aos seus objetos. A correspondência é, em última análise, uma função de critérios públicos do uso da linguagem e, portanto, de instituições sociais autorreferenciadas. O que parecia ser, então, uma reabilitação da distinção entre sujeito e objeto mediante a referência externa, depende de fato de uma complexa rede de "princípios normativos que governem a aplicação dos conceitos". A referência externa está subordinada à autorreferência ou, em outras palavras, está subordinada às "categoriais do [grupo social do] agente".

\section{Conclusão: menos assimetrias, menos insulamentos nos science studies}

As tentativas empreendidas por Latour e Bloor de conciliar realismo científico e relativismo epistemológico, independentemente de qualquer outro mérito que ainda possam ter, parecem distante de oferecer um caminho promissor para o cumprimento da agenda proposta por Kitcher para os science studies. Ambos parecem enxergar naquilo que Kitcher chamou de "quatro dogmas dos science studies" mais do que efeitos colaterais e não-tencionados de suas análises; parte desses dogmas são elementos centrais de suas respectivas teorias sociológicas da prática científica. Todavia, apenas os pontos do grupo RR são frontalmente por eles desafiados; os do grupo HS, obviamente, são ou revalorizadas (por exemplo, a teoria da referência de Bloor requer HS4) ou minimamente restringidas (por exemplo, a tese da simetria generalizada de Latour requer que HS2 seja complementada pela contraparte do par simétrico naturezasociedade). Tudo leva a crer que o dilema a ser enfrentado por qualquer 
tentativa de aproximar esses opostos seja genuinamente procustiano: ora, valorizam-se excessivamente os pontos $\mathrm{HS}$ em detrimento dos $\mathrm{RR}$, ora, o contrário; sem ser possível vislumbrar um modo de encontrar uma estabilidade em algum tipo de "meio termo", conforme a utopia de Kitcher.

Embora não seja aqui meu objetivo ir muito além de identificar o dilema acima, é importante ainda observar que há modos alternativos de encarar a solução para os impasses gerados no interior dos science studies pelo construtivismo social. Merece uma menção especial a solução proposta por Michel Friedman (1998), que, por razões diversas, é também seguida por Stephen Kemp (2005, 2007). Ambos propõem que os science studies constituam análises distintas com base em cada grupo de pontos RR e HS, de tal modo que as análises filosóficas e sociológicas sejam conduzidas de maneira autônoma e independente entre si. Na opinião de Friedman, o Programa Forte, por exemplo, se equivoca quando incorpora uma "agenda filosófica" nitidamente comprometida com o ceticismo e o relativismo filosófico. O equívoco, contudo, não está nas teses em que se sustentam essa agenda filosófica, mas antes no próprio fato de haver uma agenda de tal natureza em meio a uma prática tipicamente científica. Em outras palavras, o equívoco dos teóricos do Programa Forte é "não fazerem a distinção crucial entre a filosofia e a investigação empírica" ou não "'compartimentalizarem' os dois pontos de vista" ou, ainda, não "insularem a prática empírico-científica do Programa Forte dos efeitos corrosivos da filosofia cética e relativista". Obviamente, Friedman não compartilha os pontos de vista céticos e relativistas associados ao Programa Forte. Mas, diferente de Weinberg em sua cruzada racional-realista "contra os filósofos", ele não censura os partidários do Programa Forte por nutrirem tais pontos de vista, mas por pretenderem sustentá-los com suas pesquisas empíricas no campo da sociologia do conhecimento. Segundo Friedman, somente "insulamos com precisão a prática científica dos efeitos corrosivos da filosofia cética e relativista quando claramente segregamos a filosofia, como disciplina, da empresa científica." (1998, p. 269) Tudo isso revela que 
pretensão de solucionar os problemas tradicionais da filosofia (de fato, substituir a tradição filosófica), de outro lado. (1988, p. 241).

Virtualmente, a mesma orientação antiempirista ou anti-naturalista inspira as críticas que Stephen Kemp dirige ao Programa Forte. Ele a expressa mais diretamente ao sugerir que os sociólogos abandonem sua pretensão de, por meio de sua "agenda filosófica", desafiar a credibilidade do conhecimento científico e se dediquem a analisar como

\footnotetext{
o contexto institucional e organizacional do desenvolvimento da ciência [...] fornece as condições para que ocorram certos tipos particulares de debates e avanços científicos, conectando-os ao desenvolvimento mais amplo da sociedade em cada época e por aí afora. (KEMP, 2005, p. 718-819)
}

O insulamento recíproco das empresas filosófica e científica, tornando cada qual soberana dentro de seu próprio domínio de problemas, significaria reabilitar certas modalidades de assimetrias que os science studies pretendem ter questionado e, quiçá, superado. O equilíbrio igualitário e isonômico entre os dois grupos de pontos RR e HS parece-me ainda ser um projeto mais viável e credível. Friedman considera que a principal vítima do enfoque empirista e naturalista que o Programa Forte confere à sua "agenda filosófica" é o embotamento da percepção dos antecedentes dessa mesma agenda na história da filosofia e da maneira "insular" como ela tem sido conduzida. Hume, Carnap e o próprio Wittgenstein das Investigações Filosóficas são os exemplos invocados por Friedman de filósofos que souberam segregar claramente a filosofia, como disciplina, da empresa científica e que, assim, puderam manter essa última imune às posições relativistas ou céticas que assumiram a respeito da primeira. Sociólogos inspirados pela "agenda filosófica" do Programa Forte equivocam-se por desconhecerem essa "evolução histórica da filosofia científica" e sua interação com a "evolução histórica da própria ciência". O insulamento proposto por Friedman, portanto, não é meramente conceitual, sincrônico ou absoluto. Ele decorre de um juízo feito com base nas respectivas "evoluções históricas" da ciência e da filosofia, cuja análise criteriosa pode revelar que "há boas razões históricas por detrás da 
fascinação contemporânea pela filosofia cética e relativista" (FRIEDMAN, 1988, p. 170). É justamente isso que escapa ao maniqueísmo daqueles que tomam partido de um único grupo de pontos RR ou HS, em detrimento de seu correlato. ${ }^{5}$

Todavia, se o enfoque diacrônico ou histórico proposto por Friedman para a legitimação de uma determinada "agenda filosófica" for levado às suas últimas consequências, creio que ao menos um dos pontos elencados por Kichter não pode ser de modo algum negligenciado. Refiro-me ao ponto RR4, que sustenta a evolução histórica dos "cânones da razão e da evidência" e, por conseguinte, dos "meios pelos quais aprendemos algo sobre o mundo". Ora, por mais desajeitado e historicamente desfocado que possa ter sido até aqui o seu manuseio da "agenda filosófica" do ceticismo e do relativismo, os science studies são há mais de duas décadas parte da sua evolução histórica. A maioria dos pontos do grupo HS nem sequer seriam seriamente cogitados se autores como Latour, Barnes e Bloor não tivessem atraído a atenção dos filósofos da ciência para os ingredientes sociais dos "meios pelos quais aprendemos algo sobre o mundo". A evolução histórica proporcionada pela necessidade de considerar suas teses e, eventualmente, incorporá-las às análises filosóficas dos "cânones da razão e da evidência" é inequívoca. O desafio, neste momento, é articular um modo pelo qual isso possa ser feito sem abdicar inteiramente do grupo RR da agenda de Kitcher. Para isso, não me parece ser uma boa política anunciar qualquer nova virada à la Latour. Uma boa política seria, antes, recusar tanto insulamentos disciplinares unilaterais quanto as simetrias generalizadas. Isto é, melhor seria insistir no "meio termo" que Kitcher nos convida a considerar.

1 Para ilustrar essa tese com um famoso exemplo do próprio Latour, seria como se não fizesse qualquer sentido afirmar que a morte do faraó Ramsés II, por volta de 1213 a.C., foi causada pela tuberculose, pois ele não poderia ter morrido em virtude de um bacilo descoberto por Robert Koch somente em 1882, mais de três séculos mais tarde. Desse ponto de vista, antes de Koch, o bacilo não teria verdadeira existência. O equívoco de atribuir a morte de Ramsés II a uma infecção fatal pelo bacilo de Koch seria equivalente a 
atribuir o mesmo fato ao disparo de uma arma de fogo ou ao estresse provocado pela queda da Bolsa de Valores (GRISOTTI, 2008, p. 100).

2 O tipo de assimetria que Bloor pretende combater com seus argumentos é exemplarmente ilustrada pela seguinte defesa da relevância da explicação sociológica da ciência feita por Alan Chalmers. Segundo Chalmers, "num contexto em que os atores se empenham numa atividade com metas específicas, quando suas ações contribuem para essa meta, não é preciso haver nenhuma explicação que examine mais do que a natureza da atividade." Assim, no caso de uma prática científica que alcança suas metas específicas - que, na opinião de Chalmers, deveriam ser identificadas inteira e exclusivamente entre os pontos do grupo RR de Kitcher - não se deve esperar por qualquer outro tipo de explicação, além daquele que define a própria "natureza da atividade" científica. Para ilustrar sua tese, Chalmers imagina uma partida de futebol durante a qual a bola chega aos pés de um atacante que se encontra a poucos metros do gol do adversário, sem nada a interpor-se entre eles, nem mesmo o goleiro adversário. "Nesse contexto, não consideraríamos necessária uma explicação para a ação do jogador que chuta a bola para dentro da rede ou melhor, consideraríamos óbvia uma explicação 'interna' [isto é, em termos dos pontos do grupo RR], dadas as regras do futebol. Por outro lado, se o jogador, em vez de chutar a bola e fazer o gol, tirasse do bolso uma faca e um garfo e tentasse comê-la, ele estaria fazendo algo desprovido de sentido no contexto do jogo. Seria necessária uma explicação externa [isto é, em termos dos pontos do grupo HS], talvez recorrendo-se a informações sobre a saúde mental do jogador. [...] Isso não quer dizer que o futebol seja alguma atividade de essência divina, não-sujeita a qualquer tipo de explicação. [...] No entanto, num contexto onde estão implícitos o jogo e suas regras, as ações dos jogadores são compreendidas internamente de modo bastante satisfatório, a menos que não estejam de acordo com os objetivos do jogo." (CHALMERS, 1994, p. 124-125)

Um indício manifesto de que essa virada se aplica aos seus próprios trabalhos iniciais é a supressão do adjetivo "social" do título da sua obra de estréia Laboratory life: The social construction of scientific facts, cuja primeira edição data de 1979. A partir de 1986, o título passou a ser simplesmente Laboratory life: The construction of scientific facts. No Brasil essa obra recebeu o título A Vida de Laboratório: a produção dos fatos científicos. Além disso, desde 1999, Latour vem expressando sua aversão ao seu antigo "princípio de simetria generalizada". Num debate recente com Bloor, ele observou que "simetria (limitada ou generalizada) entre dois artefatos pode ser apenas um andaime provisório: uma vez que os artefatos são dissolvidos, a simetria não é mais necessária." (LATOUR, 1999, p. 128) Os artefatos a que Latour se refere aqui são, virtualmente, a sociedade e a natureza.

4 A tese de Bloor de que a autorreferência é condição para a referência externa somente pode ser obtida se a própria possibilidade de os conceitos possuírem conteúdo for explicada em termos das instituições sociais no interior das quais são compartilhados. Ora, em sintonia com a teoria de Wittgenstein sobre a natureza "gramatical" dos conceitos, Bloor pressupõe que um conceito somente tem conteúdo (e, portanto, significado e referência) se for possível discriminar entre as suas aplicações corretas e as incorretas. Nesse sentido, o uso de um conceito não se distingue da aplicação de uma regra - daí o seu caráter autorreferencial, isto é, que não se refere a nada exterior à convicção e ao reconhecimento a sua correta (ou incorreta) aplicação (BLOOR, 2007, p. 214-215). Não compete, todavia, ao indivíduo decidir sobre a correção do uso que faz dos conceitos. Somente o grupo social pode constituir padrões genuínos para julgar a classificação de uma determinada entidade sob certo conceito como correta ou incorreta. Tais processos autorreferenciais sustentados nos padrões da aplicação correta e incorreta dos conceitos são tipicamente exemplificados no caso da construção de conceitos socialmente compartilhados, tal como o dinheiro. $\mathrm{O}$ termo "dinheiro" refere-se a algo que corretamente é assim chamado apenas se um número suficiente de outras pessoas o reconhece como tal. A referência do termo "dinheiro" é, assim, uma realidade constituída pela prática social de fazer-lhe referência. "Assim como o dinheiro é criado por processos auto-referenciais [...], do mesmo modo são construídos os padrões de aplicação correta ou errada e, consequentemente, o conteúdo dos conceitos." (BLOOR apud KEMP, 2005, p. 710) A construção dos conceitos como 
instituições sociais (autorreferenciadas) é, pois, condição para a explicação da sua referência à realidade externa, ao invés de um modo de negar tal referência.

5 Da mesma forma que Friedman, Latour está convencido de que os problemas do Programa Forte relacionam-se, de alguma maneira, com a sua adesão a um naturalismo filosófico. Mas Latour localiza o naturalismo de Bloor não num plano meta-filosófico, como faz Friedman, mas no plano ontológico, isto é, no mesmo plano que Latour acredita ter unificado sociedade e natureza pela distribuição isonômica da agência entre ambos. "Quando insiste na necessidade de promover a diferença que tenho questionado desde o começo, Bloor alinha-se aos filósofos da ciência mais reacionários que insistem que está tudo bem com os science studies, desde que se limitem às questões epistemológicas e deixem inteiramente de lado as questões ontológicas - que pertencem aos cientistas." (1999, p. 122) Mas não nos percamos aqui nas sutilezas do vocabulário sui generis empregado por Latour: a "diferença" (entre sociedade e natureza) referida acima promove a unidade entre ciência e filosofia no plano epistemológico, enquanto a unidade (entre sociedade e natureza) pretendida por Latour promove a diferença entre ciência e filosofia no plano ontológico. O Programa Forte, segundo Latour, "nem mesmo começou a entender as coisas mais elementares relativas à originalidade filosófica dos science studies; a metafísica deles é aquela do materialismo voltairiano. O significado que eles atribuem à investigação naturalista é inspirado no mesmo tipo de natureza subjacente ao cientificismo." (LATOUR, 1999, p. 125)

\section{Referências:}

BLOOR, David. Knowledge and Social Imagery. Chicago: University Of Chicago Press, 1991.

Anti-Latour. Studies in History and Philosophy of Science, v. 30, n. 1, p. 81-112, 1999.

Ideals and monisms: recent criticisms of the Strong Programme in the sociology of knowledge. Studies in History and Philosophy of Science, v. 38, n. 2, p. 310-334, 2007.

CHALMERS, Alan. A Fabricação da Ciência. São Paulo: Editora da Unesp, 1994.

FRIEDMAN, Michael. On the sociology of scientific knowledge and its philosophical agenda. Studies in History and Philosophy of Science, v. 29 , n. 2, p. 239-271, 1998.

GRISOTTI, Marcia A construção dos fatos científicos e a existência dos vetores de doenças. Revista Brasileira de Ciências Sociais, São Paulo, v. 23, n. 66, p. 93-103, 2008.

KUHN, Thomas. O Caminho desde a Estrutura; Ensaios filosóficos, 1970-1993, com uma entrevista autobiografica. São Paulo: Editora UNESP, 2006.

KEMP, Stephen. Saving the Strong Programme? A critique of David Bloor's recent work. Studies in History and Philosophy of Science, v. 36, n. 4, p. 706-719, 2005. 
Concepts, Anomalies and Reality: A Response to Bloor and Feher Studies in History and Philosophy of Science, v. 38, n. 1, p. 241-253, 2007.

KITCHER, Philip. A Plea for Science Studies. In: KOERTGE, Noretta (Ed.). A House Built on Sand: Exposing Postmodernist Myths about Science. Oxford: Oxford University Press, 1998. p. 32-56.

LATOUR, Bruno. One more turn after the social turn... In: McMULLIN, Ernan. (Ed.). The Social Dimension of Science. Notre Damne: Indiana University of Notre Dame Press, 1992. p. 272-294.

La clef de Berlin et autres leçons d'un amateur de sciences. Paris: La Découverte, 1993.

For David Bloor and Beyond: A Reply to David Bloor's Anti-Latour. Studies in History and Philosophy of Science, v. 30, n. 1, p. 113-129, 1999.

A Esperança de Pandora. Bauru: EDUSC, 2001.

LATOUR, Bruno; WOOLGAR, Steve. A Vida de Laboratório: a produção dos fatos cientificos. Rio de Janeiro: Relume e Dumara, 1997.

MATTEDI, Marcos A. Dilemas da simetria entre contexto social e conhecimento: a redefinição das modalidades de abordagem sociológica do problema do conhecimento. Política \& Sociedade Revista de Sociologia Política, v. 1, n. 4, p. 41-79, 2004.

SHWARTZMAN, Simon Os Dinossauros de Roraima (ou a Sociologia da Ciência e da Técnica de Bruno Latour). Novos Estudos CEBRAP, v. 39, p. 172-179, 1994.

SOKAL, Alan; BRICMONT, Jean. Imposturas Intelectuais. Rio de Janeiro: Record, 1999.

WEINBERG, Steven. Sonhos de uma teoria final. A busca das leis fundamentais da natureza. Rio de Janeiro: Rocco, 1996. 